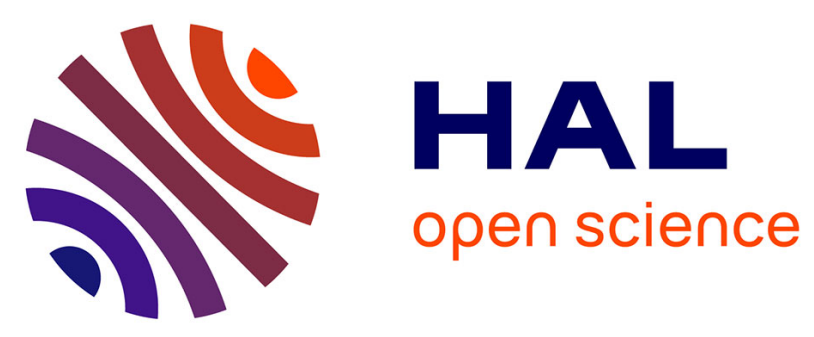

\title{
Tolerance of Japanese knotweed s.l. to soil artificial polymetallic pollution: early metabolic responses and performance during vegetative multiplication
}

Serge Michalet, Soraya Rouifed, Thomas Pellassa-Simon, Manon

Fusade-Boyer, Guillaume Meiffren, Sylvie Nazaret, Florence Piola

\section{To cite this version:}

Serge Michalet, Soraya Rouifed, Thomas Pellassa-Simon, Manon Fusade-Boyer, Guillaume Meiffren, et al.. Tolerance of Japanese knotweed s.l. to soil artificial polymetallic pollution: early metabolic responses and performance during vegetative multiplication. Environmental Science and Pollution Research, 2017, 24 (26), pp.20897-20907. 10.1007/s11356-017-9716-8 . hal-02335548

\author{
HAL Id: hal-02335548 \\ https://hal.science/hal-02335548
}

Submitted on 23 Feb 2021

HAL is a multi-disciplinary open access archive for the deposit and dissemination of scientific research documents, whether they are published or not. The documents may come from teaching and research institutions in France or abroad, or from public or private research centers.
L'archive ouverte pluridisciplinaire HAL, est destinée au dépôt et à la diffusion de documents scientifiques de niveau recherche, publiés ou non, émanant des établissements d'enseignement et de recherche français ou étrangers, des laboratoires publics ou privés. 


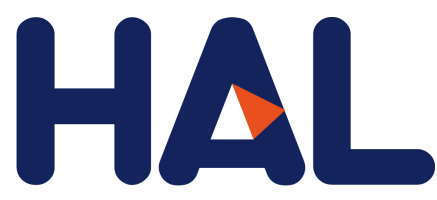

archives-ouvertes

\section{Tolerance of Japanese knotweed s.l. to soil artificial polymetallic pollution: early metabolic responses and performance during vegetative multiplication}

Serge Michalet, Soraya Rouifed, Thomas Pellassa-Simon, Manon

Fusade-Boyer, Guillaume Meiffren, Sylvie Nazaret, Florence Piola

\section{To cite this version:}

Serge Michalet, Soraya Rouifed, Thomas Pellassa-Simon, Manon Fusade-Boyer, Guillaume Meiffren, et al.. Tolerance of Japanese knotweed s.l. to soil artificial polymetallic pollution: early metabolic responses and performance during vegetative multiplication. Environmental Science and Pollution Research, Springer Verlag, 2017, 24 (26), pp.20897-20907. 10.1007/s11356-017-9716-8 . hal-02335548

\section{HAL Id: hal-02335548 \\ https://hal.archives-ouvertes.fr/hal-02335548}

Submitted on 23 Feb 2021

HAL is a multi-disciplinary open access archive for the deposit and dissemination of scientific research documents, whether they are published or not. The documents may come from teaching and research institutions in France or abroad, or from public or private research centers.
L'archive ouverte pluridisciplinaire HAL, est destinée au dépôt et à la diffusion de documents scientifiques de niveau recherche, publiés ou non, émanant des établissements d'enseignement et de recherche français ou étrangers, des laboratoires publics ou privés. 


\section{Environmental Science and Pollution Research \\ Tolerance of Japanese Knotweed s.l. to soil artificial polymetallic pollution: early metabolic responses and performance during vegetative multiplication --Manuscript Draft--}

\begin{tabular}{|c|c|}
\hline Manuscript Number: & ESPR-D-16-05798R2 \\
\hline Full Title: & $\begin{array}{l}\text { Tolerance of Japanese Knotweed s } \\
\text { metabolic responses and performar }\end{array}$ \\
\hline Article Type: & Research Article \\
\hline Corresponding Author: & $\begin{array}{l}\text { Serge Michalet } \\
\text { Universite Claude Bernard Lyon } 1 \\
\text { FRANCE }\end{array}$ \\
\hline \multicolumn{2}{|l|}{$\begin{array}{l}\text { Corresponding Author Secondary } \\
\text { Information: }\end{array}$} \\
\hline Corresponding Author's Institution: & Universite Claude Bernard Lyon 1 \\
\hline \multicolumn{2}{|l|}{$\begin{array}{l}\text { Corresponding Author's Secondary } \\
\text { Institution: }\end{array}$} \\
\hline First Author: & Serge Michalet \\
\hline \multicolumn{2}{|l|}{ First Author Secondary Information: } \\
\hline \multirow[t]{7}{*}{ Order of Authors: } & Serge Michalet \\
\hline & Soraya Rouifed, PhD \\
\hline & Thomas Pelassa-Simon, Master 1 \\
\hline & Manon Fusade-Boyer, IUT \\
\hline & Guillaume Meiffren, Master 2 \\
\hline & Sylvie Nazaret, PhD, HDR \\
\hline & Florence Piola, PhD \\
\hline
\end{tabular}

Order of Authors Secondary Information:

Funding Information:

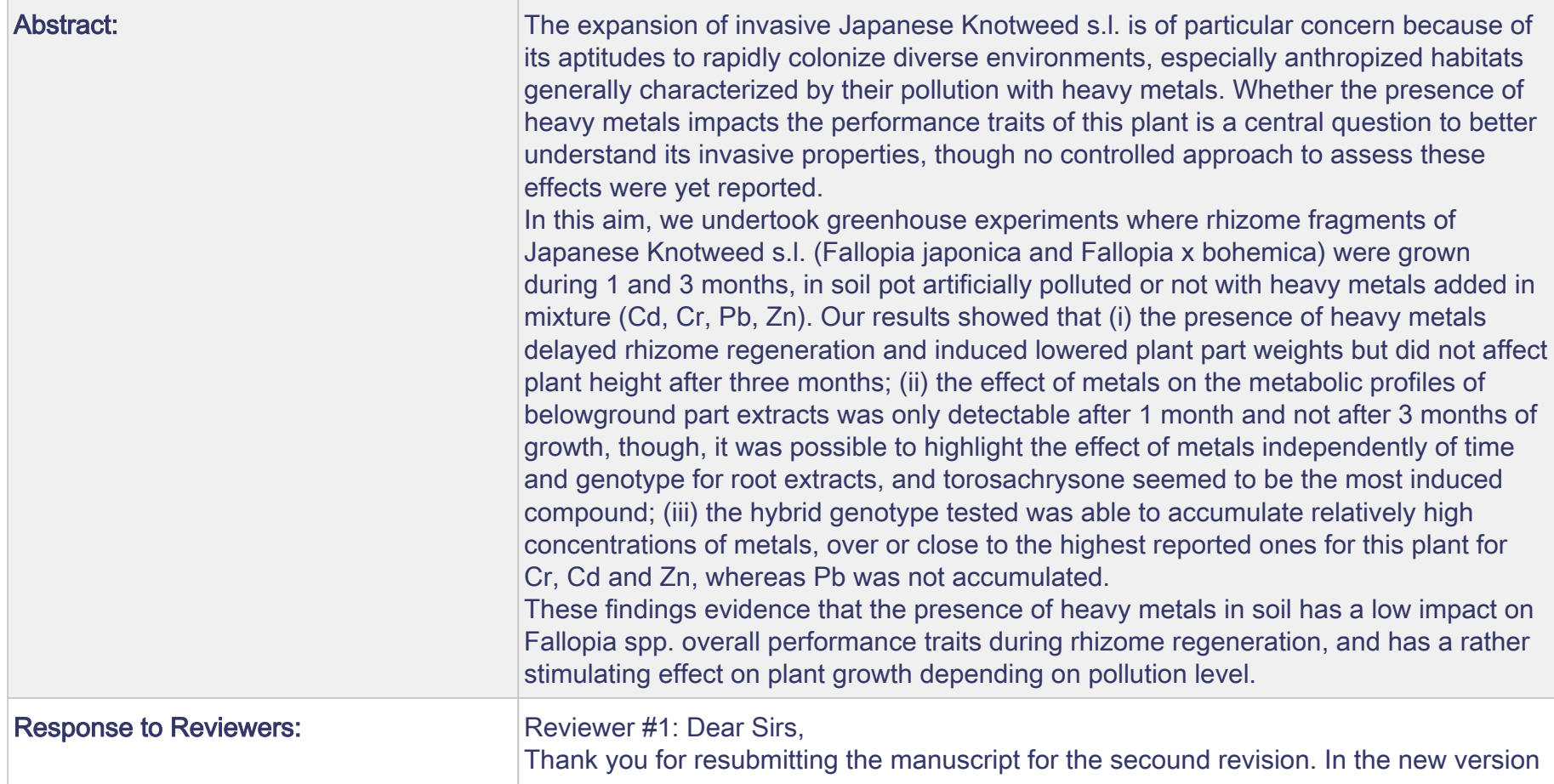




\begin{tabular}{|c|c|}
\hline & $\begin{array}{l}\text { the Authors took into account the most of suggestion, however, in my opinion this } \\
\text { report cannot be acceptable at this moment, because of the lack of some important } \\
\text { data. The manuscript is dedicated to two invasive species of the Fallopia genus } \\
\text { (Fallopia japonica and the hybrid - Fallopia } x \text { bohemica). In this study the results } \\
\text { connected with heavy metals content in investigated plants are incomplete. The author } \\
\text { did not shown the concentration of heavy metals in both species. In my opinion the } \\
\text { heavy metals in Fallopia japonica should be done. It is important, because both taxa } \\
\text { belongs to the most invasive plants in Europe. Therefore, I recommended to fill in the } \\
\text { missing results. } \\
\text { Analysis were undertaken (in the same laboratory as for F. x bohemica) and showed } \\
\text { that overall, F. japonica accumulate metals in the same ranges of what was found with } \\
\text { F. } x \text { bohemica, though differences exist: } \\
\text { In highly polluted conditions (M3 treatment) F. japonica accumulated more metals than } \\
\text { the hybrid for all the metal tested tested in the study and in all plant parts except for Cd } \\
\text { concentration in roots which was greater for F. } x \text { bohemica. } \\
\text { It is also interesting to notice that, except for Zn, F. japonica accumulated very limited } \\
\text { amounts of metals compared to F. } x \text { bohemica in the control M0 condition. Though, its } \\
\text { translocation factor varies not much in the presence of high metal concentrations (from } \\
3 \text { to } 5 \text { for Cd and from } 2 \text { to } 3 \text { for Zn in M0 and M3 conditions respectively) compared to } \\
\text { F. x bohemica for which the translocation factors of these two metals were even } \\
\text { inverted with metal contamination (from } 0,5 \text { to } 3 \text { for Zn and from } 0,1 \text { to } 1 \text { for Cd). } \\
\text { According to this, modifications were made in the manuscript in the Material and } \\
\text { Methods (lines } 176-180 \text { ), Results (lines } 275-283 \text { ) and Discussion (lines } 311-314 \text { ) of } \\
\text { the revised manuscript. } \\
\text { Figure } 7 \text { was also modified. }\end{array}$ \\
\hline \multicolumn{2}{|l|}{ Additional Information: } \\
\hline Question & Response \\
\hline §Are you submitting to a Special Issue? & No \\
\hline
\end{tabular}


1 Tolerance of Japanese Knotweed s.l. to soil artificial polymetallic pollution: early

2 metabolic responses and performance during vegetative multiplication

3

4 Serge Michalet ${ }^{\mathrm{a}}$, Rouifed Soraya ${ }^{\mathrm{b}}$, Pellassa-Simon Thomas ${ }^{\mathrm{a}}$, Fusade-Boyer Manon ${ }^{\mathrm{b}}$, Meiffren

5 Guillaume $^{\mathrm{a}}$, Nazaret Sylvie ${ }^{\mathrm{a}} \&$ Piola Florence ${ }^{\mathrm{b}}$

6

7 a Université de Lyon, Université Claude Bernard Lyon1, CNRS, UMR 5557, INRA, UMR

8 1418, Ecologie Microbienne, F-69622, Villeurbanne, France.

9 b Université de Lyon, Université Claude Bernard Lyon 1, ENTPE, CNRS, UMR 5023 LEHNA, 10 F-69622, Villeurbanne, France.

\section{* Corresponding author: serge.michalet@univ-lyon1.fr}

Key-words: Metallic trace elements, Fallopia spp. (syn. Reynoutria spp.), Plant performance traits, Metabolite profiling, Plant secondary metabolites.

\footnotetext{
Abstract

The expansion of invasive Japanese Knotweed s.l. is of particular concern because of its aptitudes to rapidly colonize diverse environments, especially anthropized habitats generally characterized by their pollution with heavy metals. Whether the presence of heavy metals impacts the performance traits of this plant is a central question to better understand its invasive properties, though no controlled approach to assess these effects were yet reported.

In this aim, we undertook greenhouse experiments where rhizome fragments of Japanese Knotweed s.l. (Fallopia japonica and Fallopia x bohemica) were grown during 1 and 3 months,
} 
26

in soil pot artificially polluted or not with heavy metals added in mixture $(\mathrm{Cd}, \mathrm{Cr}, \mathrm{Pb}, \mathrm{Zn})$. Our

27 results showed that (i) the presence of heavy metals delayed rhizome regeneration and induced 28 lowered plant part weights but did not affect plant height after three months; (ii) the effect of metals on the metabolic profiles of belowground part extracts was only detectable after 1 month and not after 3 months of growth, though, it was possible to highlight the effect of metals independently of time and genotype for root extracts, and torosachrysone seemed to be the most induced compound; (iii) the hybrid genotype tested was able to accumulate relatively high concentrations of metals, over or close to the highest reported ones for this plant for $\mathrm{Cr}, \mathrm{Cd}$ and $\mathrm{Zn}$, whereas $\mathrm{Pb}$ was not accumulated.

These findings evidence that the presence of heavy metals in soil has a low impact on Fallopia spp. overall performance traits during rhizome regeneration, and has a rather stimulating effect on plant growth depending on pollution level.

\section{Introduction}

The increased prevalence of heavy metals in the environment, which is largely due to the intensification of anthropogenic activities, is of particular concern because it affects living organisms at the whole ecosystem level. Concerning plants, two main adaptive strategy may be used to cope with an excess of heavy metals (Baker, 1981) : (i) exclusion which is the most common strategy used, where metal concentration in shoots remains low and constant while external concentration is varying, or (ii) accumulation where metal is more translocated in shoots than in roots, with the distinction between indicators that concentrate metals at levels close to that of soil and hyperaccumulators which are able to accumulate metals at very high levels (van der Ent et al. 2013; 2015).

In order to assess the effects of heavy metals on plants and better understand the molecular mechanisms involved in plant tolerance to metal stress, omics tools have been used to 
51 characterize stress-induced metabolites, phytohormones, transcription factors or proteins ( (Singh et al. 2016), as well as key genes acquired during plant evolution conferring hypertolerance (Hanikenne and Nouet, 2011). Among the metabolic changes occurring during metal exposure, plant secondary metabolites like polyphenols have been quite less studied compared to primary ones or plant hormones for example, at least qualitatively, and only an induction of polyphenol biosynthesis of metal exposed plants has been reported in a few studies, as recently reviewed by Singh et al. (2016). Though, these compounds are well-known freeradical scavengers that protect cells from oxidative stress, they also possess strong metal chelating properties, especially polymers like tannins, and they also act as molecular signals involved in many plant biotic interactions from symbiosis establishment and insect visual attraction to disease resistance (Cheynier et al. 2013). This implies that the metal-induced changes in plant polyphenol biosynthesis also probably affects plant biotic interactions, especially in the root system which is directly exposed to metal toxicity and play a major role in shaping rhizosphere microbial communities through root exudation (e.g. Michalet et al. 2013). Some authors hypothesised that this modulation of root exudates composition under contaminant exposure might select for microbes that confer plant tolerance to the stress and is referred to as the "plant call for support" theory (Thijs et al. 2016). Indeed plant-associated microbes are believed to play a great role in plant adaptation to metallic stress and this area of research has recently taken much attention, since it could be a way to drastically improve phytoremediation (Rajkumar et al. 2012; Thijs et al. 2016). Plant-microbiome interactions are also described as important drivers for the establishment of weed and invasive species (Trognitz et al. 2016). Whether invasive plant species are positively influenced by soil metal pollution, at least for those that are able to grow on metalliferous area, remains an open question that has not yet been clearly examined in the literature. Indeed, metal-polluted environments like urban or industrial settings are disturbed habitats where contaminants exert a strong selective pressure 
which render them more prompt to biological invasions (i.e. the so-called "empty niche" theory, 77 as early stated by Elton in 1958).

78 A well-known invasive species able to grow on metal polluted soil is the plants belonging to 79 the genus Fallopia (syn. Reynoutria, Polygonaceae) which includes two Asian herbaceous 80 perennial polyploid species ( $F$. japonica and $F$. sachalinensis) and their interspecific hybrid $F$. $81 \mathrm{x}$ bohemica, forming a polyploid complex of species, generally referred to as Japanese 82 Knotweed s.l. (Bailey et al. 2009). Because of their high performance traits (Bailey et al. 2009) 83 leading to dominance in the community, these species impact ecosystem functioning 84 (Dassonville et al. 2011) and pose severe socio-economical issue in Europe and North America 85 as no conventional method to efficiently control their expansion is currently known. Actually, 86 the annual cost to control Japanese Knotweed is estimated to be of more than 1.5 billion $£ /$ year 87 only for Great Britain, representing one third of the total annual cost for alien weed management 88 (Williams et al. 2010). Their capacity to tolerate abiotic stress (Rouifed et al. 2012) and their strong competitive aptitudes allow them to rapidly colonize various environments. They mainly spread by rhizome (or stem) regeneration through vegetative reproduction, though the hybrid is also able to produce seeds and back-crosses with parental species (Bailey et al. 2009, Soltysiak and Brej, 2012; Groeneveld et al. 2014; Gaskin et al. 2014). The later (F. japonica and $F$. sachalinensis) are native to Eastern Asia including volcanic areas presenting very high metallic trace elements concentrations in soil: actually more than 90 and $9000 \mathrm{mg} / \mathrm{kg}$ of Cd and $\mathrm{Zn}$ were respectively found in metalliferous site of Japan where these species naturally grow (Nishizono et al. 1989). This may in part explain why they are mainly found in anthropized environments like railroads or industrial and urban areas, and that these disturbed habitats seem to promote specifically their expansion (Soltysiak and Brej, 2012; Soltysiak and Brej, 2014). Japanese knotweed s.l. are able to accumulate metallic trace elements and the ability to concentrate toxic metals in plant parts of these species has been extensively studied, but 
exclusively from field measurements (e.g. Soltysiak et al. 2011; Rahmonov et al. 2014; Širka et al. 2016). Most of these studies reported higher amounts of metals accumulated in underground parts of the plant but no clear correlations between a rather accumulated type of metal or relationships between soil concentrations and plant metal accumulation could be made from these studies due to the variability of the published values.

Facing this, controlled studies need to be developed in order to better understand the impact of the presence of metals in soils on Japanese Knotweed s.l. performance traits, especially during vegetative propagation. In this aim we undertook greenhouse experiments, where rhizome fragments of genotypes of Japanese Knotweed s.l. were grown during one and three months respectively, in soil pot artificially polluted or not with heavy metals in mixture $(\mathrm{Cd}, \mathrm{Cr}, \mathrm{Pb}$, $\mathrm{Zn})$ at three different concentrations from faintly polluted to highly polluted soils respectively.

112 These metals were chosen because they are among the main pollutants generated by anthropic 113 activities and are often found in urban soils, and also because two of them are essential trace 114 elements $(\mathrm{Cr}$ and $\mathrm{Zn})$, whereas the two others are toxic to most organisms $(\mathrm{Cd}, \mathrm{Pb})$. To assess 115 if performance traits were impacted, the growth kinetic as well as final plant part dry weights 116 were recorded. A metabolic profiling approach on belowground plant parts (roots and rhizomes separately) and based on UV-absorbing compounds was also achieved in order to target more specifically phenolic and other aromatic compounds that might be induced during metal stress.

\section{Materials and Methods}

\section{Greenhouse experiments settings}

Two independent microcosm experiments of one month and three months respectively were 123 conducted in greenhouse. For the one month experiment which occurred between February and 124 March 2014, a loamy Luvisol (WRB, 2006) continuously cropped with maize and collected at 125 La Côte Saint-André (Isère, France) possessing the following characteristics: sand 37.5\%; loam 
126 42.7\%; clay 19.8\%; OM 2.23\%; pH 6.4; CEC: $8.79 \mathrm{cmol}^{\mathrm{kg}}{ }^{-1}$ and exempt of heavy metal

pollution, was sieved ( $2 \mathrm{~mm}$ mesh size $)$ and rehydrated to its field capacity $(28 \% \mathrm{~m} / \mathrm{v})$ by adding either Ultra-Pure water (UP) (control, M0) or a solution containing $\mathrm{Cd}, \mathrm{Cr}, \mathrm{Pb}$ and $\mathrm{Zn}$ (added as chloride salts) at concentrations close to common recognized soil pollution threshold (M2 treatment; Baize et al. 2007), ten times lower (M1 treatment) or ten times higher (M3 treatment) and summarized in Table 1. Then $200 \mathrm{~g}$ of moistened soil were placed into $0.3 \mathrm{~L}$ plastic pots and rhizome fragments of 2 genotypes of Japanese Knotweed s.l. (F. x bohemica or F. japonica) were planted. These rhizome fragments were obtained from individuals morphologically identified (F. Piola, personal communication) using leaf shape and size (Bailey et al. 2009) and collected from the field on the riverbanks of the Suran river (Ain, France) for $F$. x bohemica and on the riverbanks of the Valencizes river (Rhône, France) for $F$. japonica and that were acclimated for more than a year to greenhouse conditions in order to avoid any "mother effect". For each treatment, five budding rhizome fragments from each genotype were cut into pieces (average weight of $0.7 \pm 0.1 \mathrm{~g}$ ), planted in soil and grown in greenhouse (13h day $22^{\circ} \mathrm{C} / 11 \mathrm{~h}$ night $18^{\circ} \mathrm{C}$ ) with light intensity of about 8-10 klux. Soil moisture was manually controlled by adding water every three days. For the three months experiment which occurred between January and March 2015, the same procedure was repeated but with modifications concerning the amount of soil added in pots ( $600 \mathrm{~g}$ in order to allow the plant to grow for three months; $0.75 \mathrm{~L}$ pots). Metal concentrations were also modified because of the absence of regeneration of rhizome for the initial M3 dose chosen in the one month experiment, and in order to keep roughly an order of magnitude of difference between each treatment. Concentrations were approximatively divided by two for M1 and M2 treatments and by three for M3 treatment 148 (Table 1).

\section{Growth traits}


150 For the three months experiment, during growth, the height of each plant was notified three

times a week by measuring the distance between topsoil and the highest photosynthetic part of the plant. At the time of collection, plants were carefully excavated from soil, and roots were rinsed with tap water. Aboveground parts (stems + leaves) were separated from belowground parts (rhizome + roots) and both were immediately frozen in liquid nitrogen and freeze-dried before being weighed.

\section{Metabolite profiling of belowground parts}

157 For both experiments, after freeze-drying fine roots were separated from rhizomes, and about

$100 \mathrm{mg}$ of each were grounded (TissueLyserII ${ }^{\circledR}$ - Qiagen; F= 300/sec., 3 min.) and sonicated with a $1 \mathrm{~mL}$ mixture of $\mathrm{MeOH}-\mathrm{H}_{2} \mathrm{O}$ (1:1) for 15 minutes. After the supernatant was removed, the remaining powder was sonicated with $1 \mathrm{~mL} \mathrm{MeOH}$ and both supernatants were pooled and concentrated under vacuum (Speedvac® - Labenco) before being dissolved at $10 \mathrm{mg} / \mathrm{mL}$ in $\mathrm{MeOH} 80 \%$ and stored at $-20^{\circ} \mathrm{C}$ before analysis.

Samples were analysed by UHPLC-DAD ESI-QTOF (Agilent 1290 infinity linked with Agilent QTOF 6530), using poroshell $120 \mathrm{EC}-18$ column $(2.7 \mu \mathrm{m}, 3.0 \times 100 \mathrm{~mm}$, Agilent $)$ with a gradient of $0.1 \%$ formic acid in water (A) and acetonitrile (B) as follows: $1 \%$ of B from 0 to $1.5 \mathrm{~min}$, and growing with a linear gradient to $15 \%$ of $\mathrm{B}$ at $8 \mathrm{~min} ; 60 \%$ of $\mathrm{B}$ at 14 minutes and $100 \%$ of B at 16 min for 1 min. All solvents were LC-MS grade (Optima). The flow rate was adjusted at $1.2 \mathrm{~mL} / \mathrm{min}$ and the injection volume was $2 \mu \mathrm{L}$. UV spectra were recorded between 190 and $600 \mathrm{~nm}$. The ESI source was optimized as follows: positive ionization mode, scan spectra from $\mathrm{m} / \mathrm{z} 100$ to 2000 , capillary voltage $3.5 \mathrm{kV}$, fragmentor $120 \mathrm{~V}$, fixed collisioninduced dissociation (CID) energy at $20 \mathrm{eV}$. Nitrogen was used as the nebulizing gas with a flow rate of $12 \mathrm{~L} / \mathrm{min}$ and a temperature of $310^{\circ} \mathrm{C}$ at $40 \mathrm{psi}$.

Compounds were identified by analysis of their UV, HRMS and MS/MS spectra using MassHunter Qualitative Analysis (Agilent Technologies, USA) 


\section{Heavy metal contents in plants and soil}

Metal content in soil (three biological replicates of $F$. x bohemica rhizosphere soil) was analysed by ICP-MS at the CRPG of Vandoeuvre-les-Nancy and metal content in plant parts was analysed by ICP-MS (and ICP-radial for Zn) by USRAVE (INRA-Centre de Bordeaux ; CoFrac-certification $\left.\mathrm{n}^{\circ} 1-1838\right)$. Three replicates of both $F . \mathrm{x}$ bohemica and $F$. japonica growing in M0- and M3-treatments were analysed

\section{Statistical analysis}

\section{Growth traits}

Individual plant heights measured during the three months experiment were analysed with a dose/response model (package drc, Knezevic et al. 2007). Data obtained from both genotypes tested were pooled because they did not differ significantly.

Concerning plant part dry weights, differences between treatments, genotypes and the interaction between the two factors were analysed using variance analysis (ANOVA) on RStudio software (version 3.2.2).

\section{Metabolite profiling}

Peak areas were normalised by using relative values, i.e. percentages of each compound in the chromatogram. PCA (Principal Component Analyses) were performed using R studio software with "ade4" package. The compounds showing variations in their proportion between treatments were analysed using ANOVA, followed by a Tukey-HSD test. All tests were done in respect with the rules of normality and homoscedasticity assumptions.

195 For the one month experiment, 26 samples were analysed giving 80 peaks for rhizome extracts and 114 peaks for root extracts, whereas for the three months experiment, 42 samples were analysed with 107 peaks for rhizome extracts and 101 peaks for root extracts.

In order to compare the one month and three months experiments together, all extracts obtained during both experiments from the different biological replicates were pooled according to time 
of collection, treatment and genotype (giving 14 pooled extracts for roots and rhizome

respectively) and analysed with the same procedure of chromatography and data treatment (62 peaks analysed). As metal levels of both experiments were of the same order of magnitude data were pooled in one single matrix.

\section{Results}

\section{Growth traits}

Plant height in function of time and treatment is presented in Figure 1. Data obtained for both genotypes were analysed together because their response did not differ significantly. Pairwise comparison of parameters of the Log logistic model between treatments showed that concentration of metals affected growth of plants during time: the higher the concentration of metals, the later the plants reached $50 \%$ of their maximal height. Plants in M0 and in M1 treatments reached half of their height in 19 days. Plants in M2 treatment reached half of their height 6 days later (25 days, $\mathrm{p}<0.001$ ), and plants in M3 treatment needed further 5 days (30 days, $\mathrm{p}<0.001)$. However, plants treated with M2 concentration reached the highest height (11.6 $\mathrm{cm})$, not significantly different from plants with M3 concentration $(10.9 \mathrm{~cm}, \mathrm{p}=0.155)$, but significantly higher than plants in M0 and M1 concentrations $(10.3 \mathrm{~cm}, \mathrm{p}<0.001$ and $10.4 \mathrm{~cm}$, $217 \mathrm{p}<0.001$, respectively).

$218 F$ x bohemica had significantly higher aboveground $(\mathrm{F}=4.76, \mathrm{p}=0.035)$ and belowground $(\mathrm{F}$ $219=5.32, \mathrm{p}=0.026)$ weights than $F$. japonica after 3 months of growth. However, the genotype 220 did not influence the response of plants to the metal treatment (interactions genotype $\mathrm{x}$ 221 treatment non significant). Control plants $(\mathrm{M} 0)$ showed significantly higher aboveground $(\mathrm{F}=$ 2.95, $\mathrm{p}=0.044)$ and belowground $(\mathrm{F}=5.86, \mathrm{p}=0.002)$ weights, but treatment affected differently aerial and underground parts: plants treated with M1 concentration showed the 
224 lowest aboveground weight whereas plants treated with M2 and M3 concentrations showed the

1

lowest belowground weight.

\section{Metabolite profiling of belowground parts}

PCA based on metabolic profiles obtained from rhizome and root extracts after one and three months of growth (Fig. 3 \& Fig. 4 respectively) allowed in each case to distinguish both genotypes tested along axis 1, except for root extracts at 3 months for which this distinction was made along axis 2 (Fig. 3A, 3C \& Fig. 4A, 4C). The effect of metal treatments was detectable for both plant parts after one month of growth since M2-treated plants were relatively well separated from M0-treated plants along axis 2, and this was especially true for roots (Fig. 3B, 3D). Since the M3 treatment chosen in the one month experiment was too toxic to allow rhizome regeneration, no data could have been obtained from this group which is then lacking in the PCA. After three months of growth, it was not possible to distinguish any of the metal treated groups from the control (Fig. 4B, 4D).

In order to better characterize the effect of metal pollution on plant belowground metabolites, biological replicate extracts of both plant parts were pooled according to time, genotype and metal treatment, leading to 14 new pooled samples which underwent the same chromatographic analysis and data treatment procedure (Fig. 5). This allowed for both plant parts to distinguish the effect of time which was mainly explained by axis 1 (Fig. 5A, 5D), from that of genotype which was mainly explained by axis 2 (Fig. 5B, 5E). It was also possible to discriminate metal treated groups along axis 3 but this was only the case for root extracts (Fig. 5F) and not for rhizome extracts (Fig. 5C), even when considering lower eigen values.

One of the compound for which the proportions were the most increased with metal concentrations and strictly explaining axis 3, was identified as torosachrysone, a dihydroanthracenone derivative, by comparing its UV, HRMS and MSMS spectra with literature data (Fig. 6). Other anthracene derivatives including anthraquinone and dianthrones 
were also found to be increased in their proportions in root extracts at one and three months

(data not shown).

\section{Heavy metal contents in soil and plant parts of F. $x$ bohemica}

The content of metallic trace elements in M3-treated soil after the three months experiment was relatively close to the theoretical concentrations expected (i.e. resulting from the artificial contamination of soil experimented in this study) for $\mathrm{Cd}(7.2 \pm 0.5 \mathrm{mg} / \mathrm{kg} v s 5.5 \mathrm{mg} / \mathrm{kg}$ in theory), $\mathrm{Cr}(332.0 \pm 39.2 \mathrm{mg} / \mathrm{kg} v s 440.0 \mathrm{mg} / \mathrm{kg}$ in theory) and $\mathrm{Zn}(923.7 \pm 70.5 \mathrm{mg} / \mathrm{kg} v s 880.0$ $\mathrm{mg} / \mathrm{kg}$ in theory), whereas for $\mathrm{Pb}$, the measured concentration was approximatively divided by three compared to its theoretical concentration $(95.9 \pm 8.3 \mathrm{mg} / \mathrm{kg} v s 295.0 \mathrm{mg} / \mathrm{kg}$ in theory) (Fig. 7 and Table 1).

259 The control soil M0 that received no metallic treatment showed low heavy metal concentrations 260 as expected, in the range of what is naturally found for this type of soil, and could thus be 261 considered as non-polluted.

262 F. x bohemica accumulated metals even if no artificial pollution was added (i.e. M0-treatment; 263 Fig. 7A-D-left), and especially in underground parts: similar contents than those found in soil 264 were actually measured for $\mathrm{Cr}$ and $\mathrm{Zn}$ (Fig. 7B and 7D respectively). In contrast Cd was 265 accumulated approximatively five times more (Fig. 7A) and $\mathrm{Pb}$ six time less (Fig. 7C). These 266 metals did not seem to be translocated to aerial parts in these conditions since metal 267 concentrations were very low and close to the limit of quantification for $\mathrm{Cd}, \mathrm{Cr}$ and $\mathrm{Pb}$.

268 When artificial metallic pollution was added at the highest concentration tested (i.e. M3269 treatment; Fig. 7A-D-right), each metal except $\mathrm{Pb}$ was more accumulated in $F$. $\mathrm{x}$ bohemica plant parts and the translocation factor $\left([\text { metal }]_{\text {shoots }} /[\text { metal }]_{\text {roots }}\right)$ of Cd was increased ten times compared to control (1.0 vs 0.1 ; Fig. 7A) and six times for $\mathrm{Zn}(3.3$ vs 0.5 ; Fig. 7D). The highest concentrations of metal in $F$. x bohemica measured for this treatment were of $507.0 \mathrm{mg} / \mathrm{kg}$ for 
$273 \mathrm{Zn}$ in aerial parts, and of 127.0 and $14.0 \mathrm{mg} / \mathrm{kg}$ for $\mathrm{Cr}$ and $\mathrm{Cd}$ respectively in belowground

1

2

3

4

parts.

By comparison, in the M3 condition $F$. japonica accumulated more of each metal than the hybrid, especially $\mathrm{Zn}$ and $\mathrm{Cd}$, for which, concentrations were as high as 833.0 and $19.5 \mathrm{mg} / \mathrm{kg}$ respectively in aerial parts of some individuals, and of up to $244.0 \mathrm{mg} / \mathrm{kg}$ for $\mathrm{Cr}$ in belowground parts whereas $\mathrm{Pb}$ was also poorly accumulated (Fig. 7A-D right).

It is also interesting to notice that, except for $\mathrm{Zn}, F$. japonica accumulated very limited amounts of metals compared to $F$. x bohemica in the control M0 condition (Fig. 7A-D left). Though, its translocation factor varies not much with the presence of high concentrations of metal (from 3 to 5 for $\mathrm{Cd}$ and from 2 to 3 for $\mathrm{Zn}$ in $\mathrm{M} 0$ and $\mathrm{M} 3$ conditions respectively) compared to $F$. $\mathrm{x}$ bohemica.

\section{Discussion}

In this study we assessed the effect of an artificial polymetallic pollution of soil on Fallopia spp. performance, and more precisely its impact on rhizome regeneration and growth occurring in the early stages of vegetative propagation, as well as its impact on belowground secondary metabolism.

Our results showed that the presence of heavy metals in soil induced a delay for plants to reach half of their maximal height, delay that was more pronounced with high metal concentrations. Though, after three months of growth, plant final height of both genotypes was not impacted by metal pollution and it was even significantly greater for M2-treated group compared to control. This implies that plant growth speed was higher when metals were present. The observed delay in rhizome regeneration induced by metallic pollution could be correlated with the fact that metabolic changes in belowground parts of the plant were only observed after one month of growth and not after three. This suggests that the delay in rhizome regeneration induced by the presence of metals is due to plant investment in the production of secondary 
metabolites rather than in primary metabolites needed for cell and tissue multiplications (as

demonstrated in the "grow or defend" theory; Herms and Mattson, 1992). It also correlates with the fact that lowered plant part weights were measured in metal-treated groups. One of the plant growth traits affected by metal treatment was belowground part weight which was reduced when metals were added at high concentrations suggesting a toxic effect. On the other hand, aerial parts were not affected by these treatments indicating that this plant shows an overall good tolerance to metal stress regarding the concentrations added. The fact that aerial part weight was affected with low doses of metals (i.e. M1-treatment) reveals that this plant might be very sensitive to soil metal concentrations.

Concerning plant metal accumulation, the reported values of this study are in the range of the highest published, except for $\mathrm{Pb}$ which was not accumulated and $\mathrm{Cr}$ which was found at concentrations up to three times more than those reported in underground parts and up to ten times in aerial parts (Fig. 6 and Table 2). The fact that $\mathrm{Cr}$ was present at concentrations up to 8 times higher in soil may explain in part these results. Of particular interest is the fact that $\mathrm{Zn}$ and $\mathrm{Cd}$ translocation factors were increased in the case of $F$. japonica and even inverted in the case of $F$. x bohemica with $\mathrm{Cd}$ and $\mathrm{Zn}$, when plants were exposed to high metal concentrations, suggesting a change in plant nutritional strategy. Although these observations are interesting for the potential valorisation of this plant in phytoremediation of contaminated sites, caution must be taken for the extrapolation of these results to what occurs in situ, since we only worked on young shoots which may accumulate more than old ones, and as stressed by Van der Ent et al. (2012), these types of controlled-approaches have very limited relevance in explaining what occurs in natural environment although the polymetallic contamination applied in our study is 320 probably closer to what happens in urban ecosystems for example. In all cases further 321 mesocosm and field studies are required to confirm the results obtained. 
The consequences of metal accumulation in the plant and its relative high tolerance and

sensitivity to polymetallic stress let us hypothesize that these traits may serve the plant to rapidly colonize diversely polluted environments, where other plant species might be excluded because of the presence of metals in soils. Herbivory may also be limited because of metal accumulation in plant aerial parts which may have a repellent effect on predators (especially young shoots that may be more prompt to herbivory attacks; Price 1991). The molecular mechanisms involved in metal tolerance remain to be elucidated, though the metabolic profiling approach undertook in this study might bring some clue about the secondary metabolites directly or indirectly involved in metal tolerance. Torosachrysone was identified as one of the compound for which the relative proportions were the most increased in roots with metal concentrations, this independently of plant age or genotype. To our knowledge this is the first report of this compound in this genus. It has been described to be involved in anthraquinone biosynthesis (Abdel-Rahman et al. 2013), compounds that are well known in Fallopia spp. (Piola et al. 2013), and that have also been characterized with higher relative proportions in metal-treated plant roots in this study (data not shown). The exact role of torosachrysone in metal tolerance and/or accumulation is still to be elucidated but from the results of our study, it seems to be well involved directly or indirectly in plant adaptation to metallic stress. Following the "plant call for support theory" emitted by Thijs et al. (2016), this compound could have an impact on the selection of rhizosphere microbes possessing the ability to improve plant tolerance to metallic stress. Further experiments including field studies should be conducted in order to confirm these findings, for example the correlation between torosachrysone content in roots and heavy metal content in plant or soil collected in situ could be interesting to analyse. 344 The production of torosachrysone by fungal strain has also been reported (Gill, 2003; Müller et 345 al. 2004) leading to the hypothesis that this compound might be produced by fungal endophytes. 346 The presence of such associated microbes has recently been shown in this plant through the 
identification of Dark Septates Endophytes (DSE) microsclerotia colonizing roots (Gucwa-

Przepióra et al. 2016). These fungal endophytes, which are characterized by their melanised and septate hyphae, are frequent associated root endophytes of herbaceous plants. They have been described as important determinants influencing plant tolerance to heavy metal stress because they are able to tolerate high concentration of metallic trace elements, notably through the increase of melanin which enables to decrease metal toxicity (Ban et al. 2012). Whether these micro-organisms play a role in Fallopia adaptation to heavy metal stress remains to be confirmed, but the findings of our study in the light of recent literature on the subject let us suggest that it is the case.

\section{Conclusion}

358 To conclude, our findings evidenced that the presence of toxic metals in soil had a low impact on Japanese Knotweed s.l. overall performance traits during vegetative propagation, and had a rather stimulating effect on plant growth depending on pollution level:

- the presence of metal in soil induced a change in plant belowground secondary metabolism which only occurs at early stages of plant vegetative propagation and this might be correlated with the observed metal-induced delay in rhizome regeneration and with lowered plant part weights under metal stress.

- on the other hand the fact that plant final height was not affected (or even increased at some concentrations), and that plant metal accumulation and nutritional strategies were modified depending on metal concentrations in soil, might suggest that this plant is very sensitive to the presence of metal in soil and that it may explain, at least in part, its capacity to rapidly colonize anthropized metal-polluted environments. All these results need to be confirmed with further in situ studies and/or controlled mesocosm studies using naturally polluted soils. 


\section{Acknowledgements}

This study was funded by Initiative Structurante EC2CO (Ecosphère Continentale et Cotière) -

ECODYN (Ecotoxicologie, Ecodynamique des contaminants) and FR3728 BioEnviS

(Université Claude Bernard Lyon1).

We also thank the 'Serre et chambres climatiques' platform (Université Claude Bernard Lyon1, FR3728) and Elise Lacroix for her help with plant culture.

\section{References}

Abdel-Rahman IAM, Beuerle T, Ernst L, Abdel-Baky AM, Desoky EEDK, Ahmed AS, Beerhues L (2013) In vitro formation of the anthranoid scaffold by cell-free extract from yeastextract-treated Cassia bicapsularis cell cultures. Phytochem 88:15-24

Bailey JP, Bimova K, Mandak B (2009) Asexual spread versus sexual reproduction and evolution in Japanese Knotweed s.l. sets the stage for the "Battle of the Clones". Biol Invasions 11:1189-1203

Baize D, Deslais W, Saby NPA, Bispo A, Feix I (2007) Analyses totales et pseudo-totales d'éléments en trace dans les sols. Principaux résultats et enseignement d'une collecte nationale.

Etude et Gestion des Sols 13:180-200

Baker AJM (1981) Accumulators and excluders - strategy in the response of plants to heavy metals. J Plant Nutr 3:643-654 
Ban Y, Tang M, Chen H, Xu Z, Zhang H, Yang Y (2012) The response of Dark Septate 420

Cheynier V, Comte G, Davies KM, Lattanzio V, Martens S (2013) Plant phenolics: recent advances on their biosynthesis, genetics, and ecophysiology. Plant Physiol Biochem 72:1-20

Dassonville N, Guillaumaud N, Piola F, Meerts P, Poly F (2011) Niche construction by the invasive Asian knotweeds (species complex Fallopia): impact on activity, abundance and community structure of denitrifiers and nitrifiers. Biol Invasions 13:1115-1133

Elton, C.S. (1958).The ecology of invasions of animals and plants. Methuen, London

Gaskin JF, Schwarzländer M, Grevstad FS, Haverhals MA, Bourchier RS, Miller TW (2014)

Extreme differences in population structure and genetic diversity for three invasive congeners:

knotweeds in western North America. Biol Invasions 16:2127

Gill M (2003) Pigments of fungi (Macromycetes). Nat Prod Rep 20:615-639

414 Groeneveld E, Belzile F, Lavoie C (2014) Sexual reproduction of Japanese Knotweed (Fallopia 415 japonica S.L.) at its northern distribution limit: new evidence of the effect of climate warming 416 on an invasive species. Am J Bot 101:459-466

418 Gucwa-Przepióra E, Chmura D, Sokolowska K (2016) AM and DSE colonization of invasive 419 plants in urban habitat: a study of Upper Silesia (southern Poland). J Plant Res 129:603-614 
6

Hanikenne M, Nouet C (2011) Metal hyperaccumulation and hypertolerance: a model for plant evolutionary genomics. Curr Opin Plant Biol 14:252-259

Herms DA, Mattson WJ (1992) The dilemma of plant: to grow or defend. Q Rev Biol 67:283334

Knezevic SZ, Streibig JC, Ritz C (2007) Utilizing R software package for dose-response studies: The concept and data analysis. Weed Technol 21:840-848

Michalet S, Rohr J, Warshan D, Bardon C, Roggy J-C, Domenach A-M, Czarnes S, Pommier T, Combourieu B, Guillaumaud N, Bellvert F, Comte G, Poly F (2013) Phytochemical analysis of mature tree root exudates in situ and their role in shaping soil microbial communities in relation to tree N-acquisition strategy. Plant Physiol Biochem 72:169-177

Müller M, Lamottke K, Löw E, Magor-Veenstra E, Steglich W (2000) Stereoselective total syntheses of atrochrysone, torosachrysone and related 3,4-dihydroanthracen-1(2H)-ones. J Chem Soc Perkin Trans 1 15:2483-2489

Müller M, Lamottke K, Steglich W, Busemann S, Reichert M, Bringmann G, Spiteller P (2004) Biosynthesis and stereochemistry of phlegmacin-type fungal pigments. Eur J Org Chem $23: 4850-4855$

Nishizono H, Kubota K, Suzuki S, Ishii F (1989) Accumulation of heavy metals in cell walls of Polygonum cuspidatum roots from metalliferous habitats. Plant Cell Physiol 30:595-598 
446 Piola F, Bellvert F, Meiffren G, Rouifed S, SWalker V, Comte G, Bertrand C (2013) Invasive

Fallopia $\times$ Bohemica interspecific hybrids display different patterns in secondary metabolites.

Ecoscience 20:230-239

Price PW (1991) The plant vigor hypothesis and herbivore attack. Oikos 62:244-251

Rajkumar M, Sandhya S, Prasad MNV, Freitas H (2012) Perspectives of plant-associated microbes in heavy metal phytoremediation. Biotechnol Adv 30:1562-1574

Singh S, Parihar P, Singh R, Singh VP, Prasad SM (2016) Heavy metal tolerance in plants: role of transcriptomics, proteomics, metabolomics, and ionomics. Front Plant Sci 6:1143

Širka VH, Jakovljević K, Mihailović N, Jovanović S (2016) Heavy metal accumulation in invasive Reynoutria x bohemica Chrtek \& Chrtkova in polluted areas. Environ Earth Sci 75:951

Sołtysiak J, Berchová-Bímová K, Vach M, Brej T (2011) Heavy metals content in the Fallopia genus in Central European Cities - study from Wroclaw and Prague. Acta Botanica Silesiaca 7:209-218

Sołtysiak J, Brej T (2012) Characteristics that make the Fallopia genus (Polygonaceae) highly invasive. Ecological Questions 16:23-27

468 Sołtysiak J, Brej T (2014) Invasion of Fallopia genus plants in Urban Environment. Pol J 469 Environ Stud 23:449-458 
Rahmonov O, Czylok A, Orczewska A, Majgier L, Parusel T (2014) Chemical composition of

the leaves of Reynoutria japonica Houtt. and soil features in polluted areas. Cent Eur J Biol 9:320-330

Rouifed S, Byczek C, Laffray D, Piola, F (2012) Invasive Knotweeds are highly tolerant to salt stress. Environ. Manage 50:1027-1034

Van der Ent A, Baker AJM, Reeves RD, Pollard AJ, Schat H (2012) Hyperaccumulators of metal and metalloid trace elements: facts and fiction. Plant Soil 362:319

Van der Ent A, Baker AJM, Reeves RD, Pollard AJ, Schat H (2015) Commentary: toward a more physiologically and evolutionary relevant definition of metal hyperaccumulation in plants. Front Plant Sci 6:554

Williams F, Eschen R, Harris A, Djeddour D, Pratt C, Shaw RS, Varia S, Lamontagne-Godwin J, Thomas SE, Murphy ST (2010) The economic cost of invasive non-native species on Great Britain. CABI Publishing, Wallingford

\section{Table legends:}

Table 1. Theoretical metal concentration achieved in soil (in $\mathrm{mg} / \mathrm{kg}$ ) after artificial pollution in function of treatment

Table 2. Highest reported values of heavy metal concentrations (in $\mathrm{mg} / \mathrm{kg}$ ) in soil and plant parts of Fallopia spp. Reference literature in which values were published is indicated:

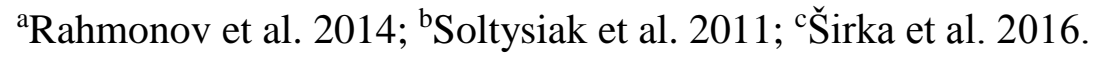


Figure legends:

Figure 1. Evolution of mean height $(\mathrm{cm})$ of plant individuals during time (days after plantation), displayed in function of metal treatment for the three months experiment. Small figures represent raw data ( $\circ \mathrm{M} 0, \Delta \mathrm{M} 1,+\mathrm{M} 2, \mathrm{x}$ M3) and curves were calculated with the model.

Figure 2. Plant aboveground (A) and belowground (B) dry weights in function of metal treatment (mean \pm S.E.). Statistically significant changes compared to control M0 are highlighted $(* \mathrm{p} \leq 0.05, * * \mathrm{p} \leq 0.01)$.

Figure 3. Principal Component Analyses (PCA) of rhizome (A, B) and root $(\mathbf{C}, \mathbf{D})$ extracts obtained after 1 month of growth and based on UV-absorbing compound chromatographic profiles integrated at $280 \mathrm{~nm}$ and expressed as relative peak areas. Genotypes $(\mathbf{A}, \mathbf{C})$ and metal treatments $(\mathbf{B}, \mathbf{D})$ are displayed following PC1 and PC2: for rhizome extracts PC1 $=24.4 \%$ and $\mathrm{PC} 2=20.3 \%(\mathrm{~N}=26$ samples; 80 peaks $)$ and for root extracts $\mathrm{PC} 1=33.4 \%$ and $\mathrm{PC} 2=15.4 \%$ $(\mathrm{N}=26$ samples; 114 peaks).

511 Figure 4. Principal Component Analyses (PCA) of rhizome (A, B) and root (C, D) extracts obtained after 3 months of growth and based on UV-absorbing compound chromatographic profiles integrated at $280 \mathrm{~nm}$ and expressed as relative peak areas. Genotypes $(\mathbf{B}, \mathbf{C})$ and metal treatments $(\mathbf{B}, \mathbf{D})$ are displayed following PC1 and PC2: for rhizome extracts $\mathrm{PC} 1=27.9 \%$ and $\mathrm{PC} 2=17.6 \%(\mathrm{~N}=45$ samples; 107 peaks $)$ and for root extracts $\mathrm{PC} 1=23.9 \%$ and $\mathrm{PC} 2=15.2 \%$ ( $\mathrm{N}=45$ samples; 101 peaks).

Figure 5. Principal Component Analyses $(\mathrm{PCA})$ of rhizome $(\mathbf{A}, \mathbf{B})$ and root $(\mathbf{C}, \mathbf{D})$ pooled extracts and based on UV-absorbing compound chromatographic profiles integrated at $280 \mathrm{~nm}$ 519 and expressed as relative peak areas. Duration of experiment $(\mathbf{A}, \mathbf{D})$ and genotypes $(\mathbf{B}, \mathbf{E})$ are 520 displayed following PC1 and PC2, whereas metal treatments $(\mathbf{C}, \mathbf{F})$ are displayed following 
$521 \mathrm{PC} 1$ and PC3: for rhizome extracts $\mathrm{PC} 1=26.0 \%, \mathrm{PC} 2=17.3 \%$ and $\mathrm{PC} 3=6.9 \%(\mathrm{~N}=14$ samples;

1

64 peaks $)$ and for root extracts $\mathrm{PC} 1=20.6 \%, \mathrm{PC} 2=12.6 \%$ and $\mathrm{PC} 3=9.1 \% .(\mathrm{N}=14$ samples; 62 peaks).

Figure 6: Molecular structure of torosachrysone (A), its experimental UV spectra (B) which is similar to what was described by Müller et al. (2000) for the compound (R)-[methoxy${ }^{13} \mathrm{C}$ ]torosachrysone (R)-2, and its experimental HRMS $\left(\mathrm{m} / \mathrm{z}\right.$ : $[\mathrm{M}+\mathrm{H}]^{+}$calc. for $\mathrm{C}_{16} \mathrm{H}_{17} \mathrm{O}_{5}$ : 527 289.1076, found 289,1074; match score 98\%) and MSMS spectra in positive mode (C). The 528 later was identical to the data presented by Abdel-Rahman et al. (2013) in which a 529 fragmentation pattern is also proposed for this molecule, pattern confirmed by HRMS data of 530 this study.

531 Figure 7: Heavy metal content (Cd: A; Cr: B; Pb: C; Zn: D; in mg/kg) in soil and plant parts 532 of $F$. japonica $(\mathrm{Fj})$ and $F$. x bohemica $(\mathrm{Fxb})$ grown in M0- and M3-treated groups (mean \pm S.D. 533 of 3 biological replicates in each case). BP: belowground parts; AP: aboveground parts. 


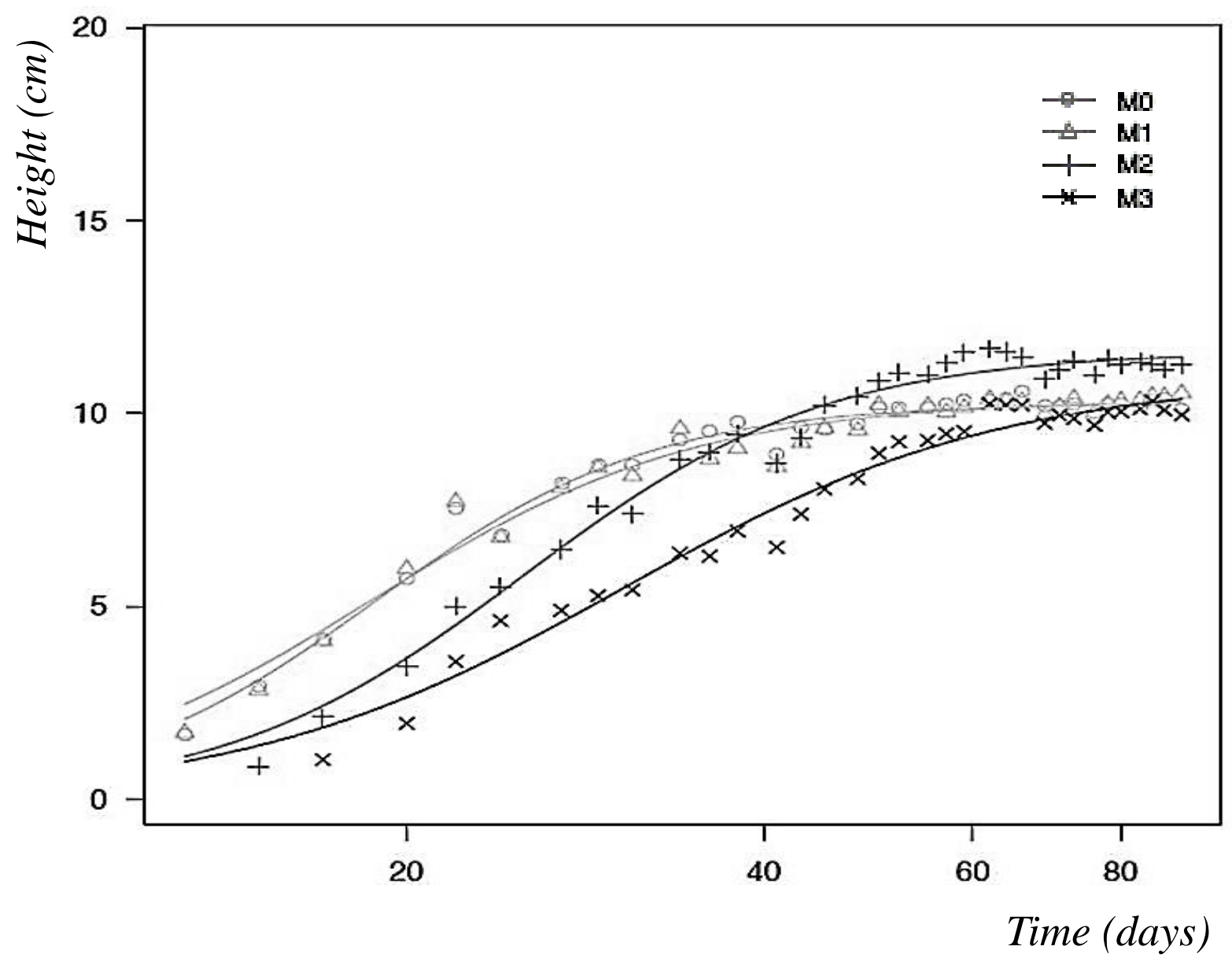

Figure 1 
A

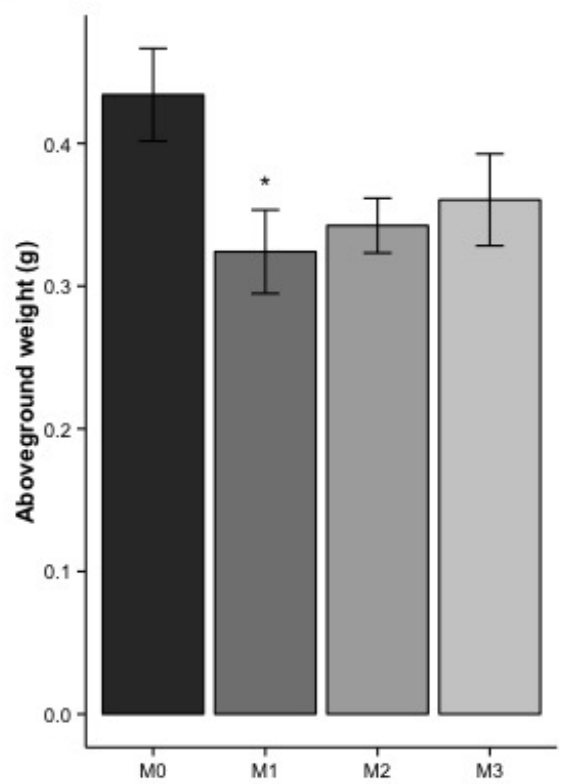

B

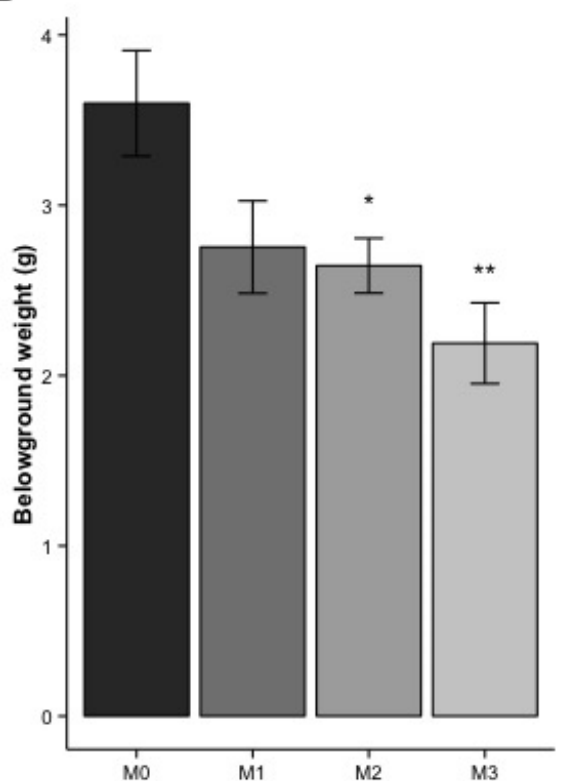

Figure 2 

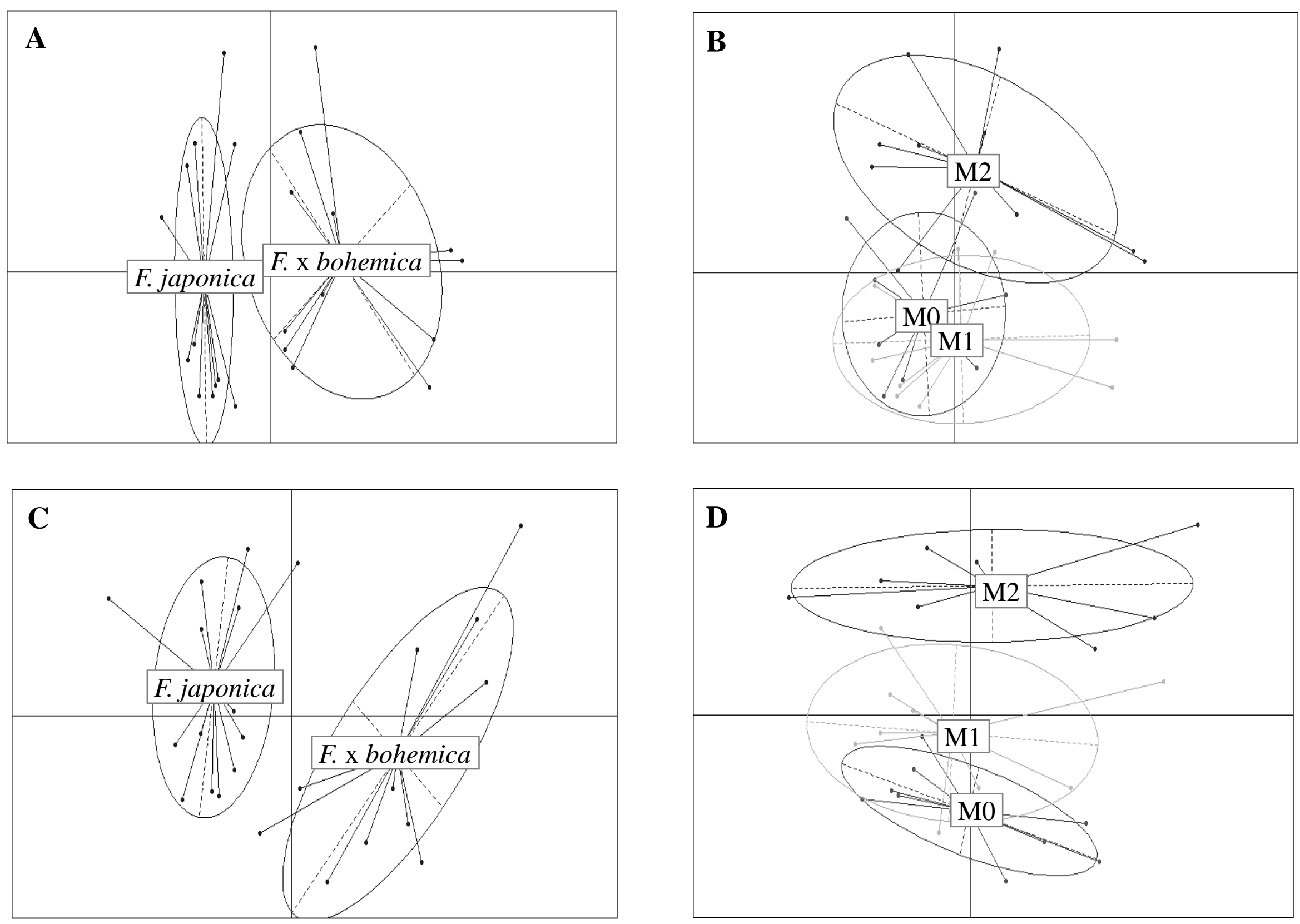

Figure 3 

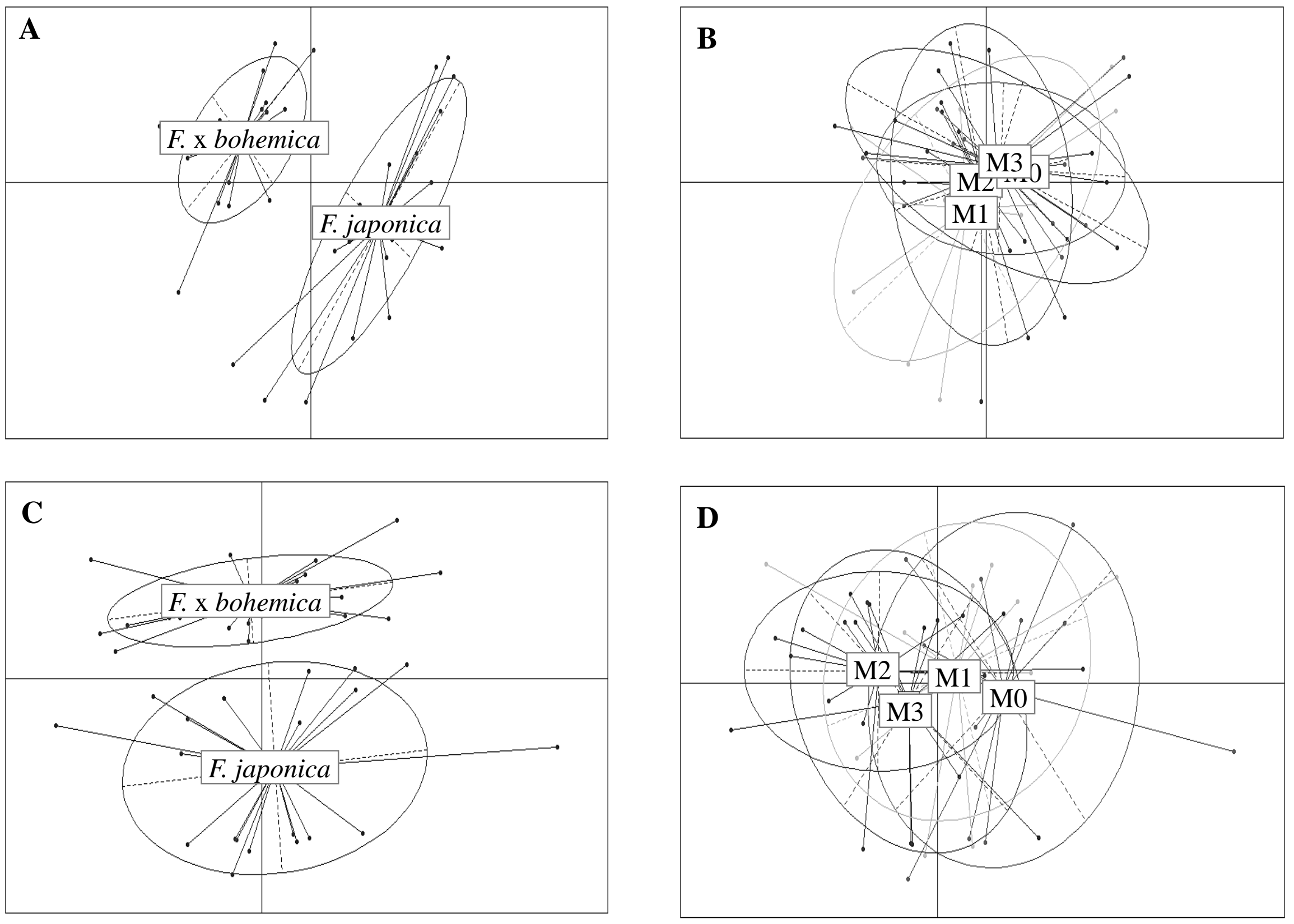

Figure 4 

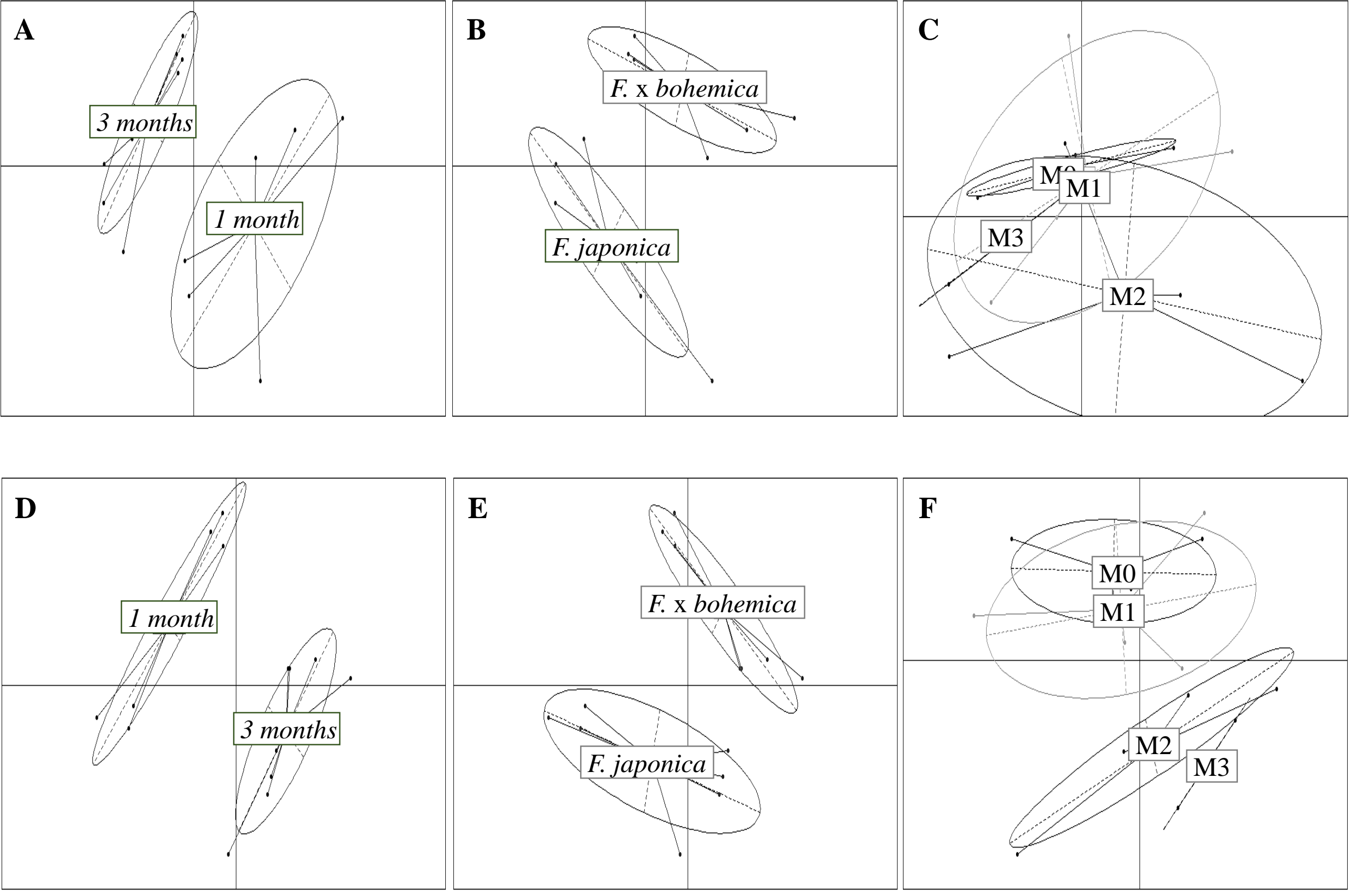

Figure 5 

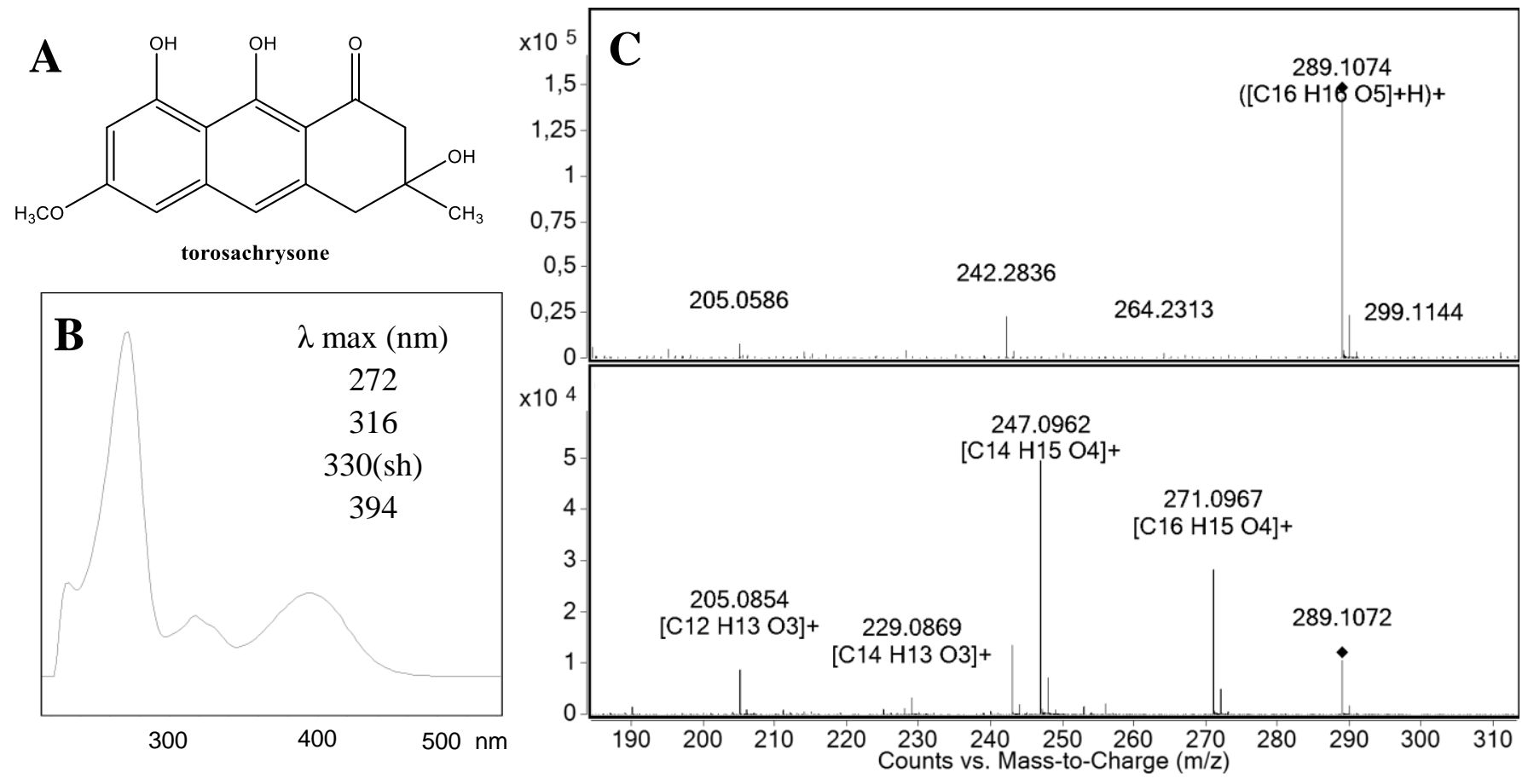

\section{Figure 6}




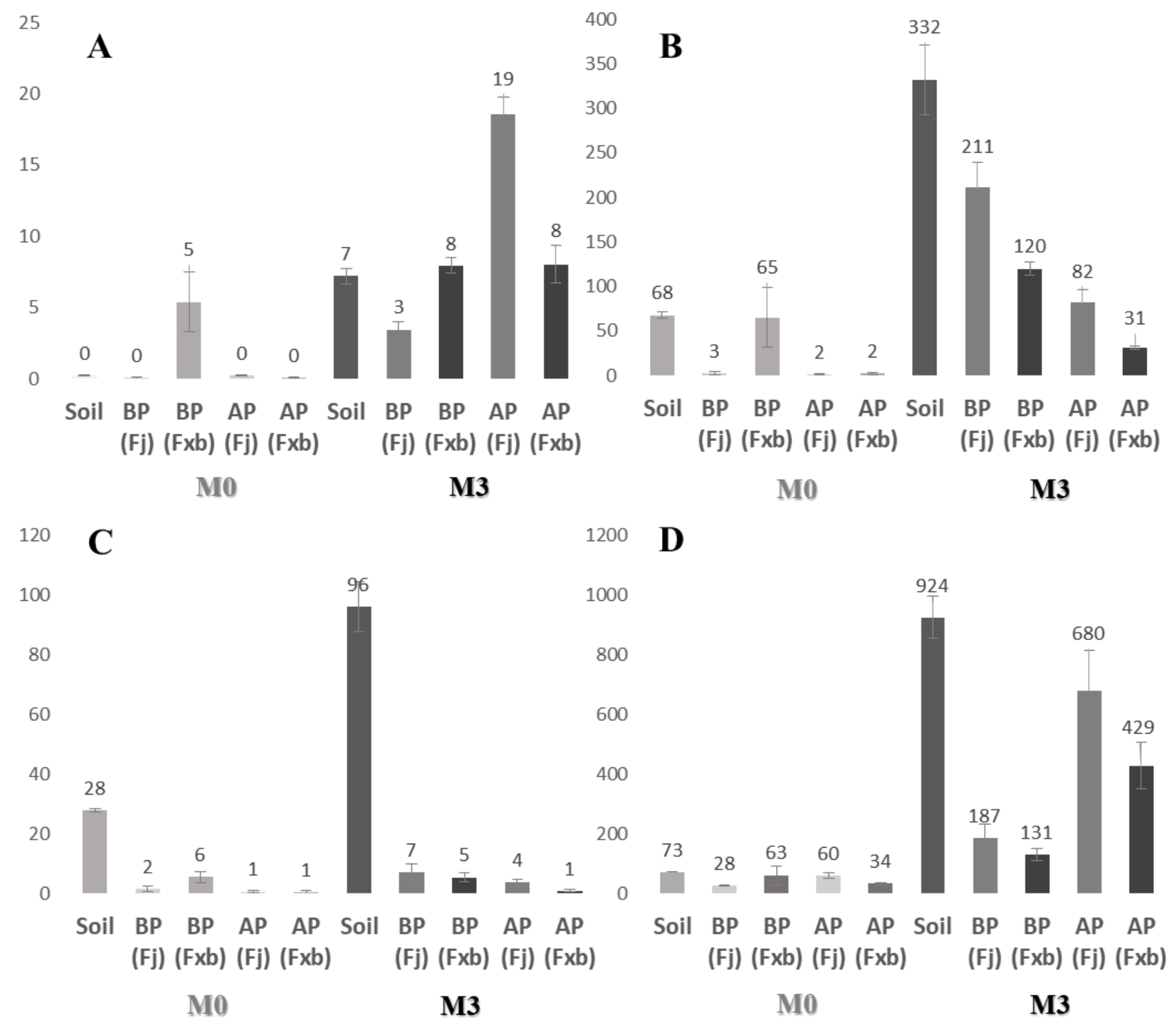

Figure 7 


\begin{tabular}{|c|c|c|c|c|c|c|c|}
\hline \multirow{2}{*}{ Metals } & \multirow{2}{*}{$\begin{array}{c}\text { Non polluted } \\
(\mathrm{M} 0)\end{array}$} & \multicolumn{2}{|c|}{$\begin{array}{c}\text { Polluted +/- } \\
(\mathrm{M} 1)\end{array}$} & \multicolumn{2}{c|}{$\begin{array}{c}\text { Polluted + } \\
(\mathrm{M} 2)\end{array}$} & \multicolumn{2}{c|}{$\begin{array}{c}\text { Polluted ++ } \\
(\mathrm{M} 3)\end{array}$} \\
\cline { 3 - 8 } & & 1 month & 3 months & 1 month & 3 months & 1 month & 3 months \\
\hline $\mathrm{Cd}$ & 0 & 0.2 & 0.1 & 2 & 1 & 20 & 6 \\
\hline $\mathrm{Cr}$ & 0 & 15 & 9 & 150 & 90 & 1500 & 440 \\
\hline $\mathrm{Pb}$ & 0 & 10 & 6 & 100 & 60 & 1000 & 295 \\
\hline $\mathrm{Zn}$ & 0 & 30 & 18 & 300 & 180 & 3000 & 880 \\
\hline
\end{tabular}

Table 1 


\begin{tabular}{|c|c|c|c|}
\hline Metals & Soil & $\begin{array}{c}\text { Underground } \\
\text { parts }\end{array}$ & Aerial parts \\
\hline $\mathrm{Cd}$ & $6.7^{\mathrm{a}}$ & $19.7^{\mathrm{b}}$ & $6.7^{\mathrm{b}}$ \\
\hline $\mathrm{Cr}$ & $59.8^{\mathrm{b}}$ & $40.9^{\mathrm{b}}$ & $2.7^{\mathrm{c}}$ \\
\hline $\mathrm{Pb}$ & $203.0^{\mathrm{b}}$ & $27.3^{\mathrm{b}}$ & $10.7^{\mathrm{c}}$ \\
\hline $\mathrm{Zn}$ & $2623.0^{\mathrm{b}}$ & $357.0^{\mathrm{b}}$ & $541.7^{\mathrm{a}}$ \\
\hline
\end{tabular}

Table 2 
Click here to access/download Supplementary Material Michalet_et_al_second revision_with corrections.docx 